\title{
Coastal dune vegetation: dynamic and influence of anthropo- genic factors
}

\author{
Haddad Fatma Zohra*, Benaissa Noureddine, El-Hadj Zoubida, Temimi Yousra, Bekratou Djamel, Kallouche \\ Mohamed Mustapha, Belkhoudja Moulay \& Mouffok Salim
}

Environmental Monitoring Network Laboratory, Faculty of Nature and Life Sciences, Department of Biology, University Oran 1, Algeria

*Corresponding author, e-mail: n benaissa@yahoo.fr

\begin{abstract}
This study describes the vegetation dune systems status in relation to antroipogenic disturbance factors in the coastal stretch of the Madrague area in Algeria. This study was carried out during the spring and summer of 2018. Particular emphasis was given to flora composition by assessing their frequency and diversity. Vegetation sampling was carried out along twenty shore-perpendicular transects recording different data. The flora inventoried highlights a strong dominance of the Asteraceae family, which accounts for $24.32 \%$ of all inventoried species. Analysis of the biological spectrum shows the predominance of therophytes, with rate of $32.43 \%$, indicating an average degradation whose origin is anthropogenic action. The IP disturbance index of our study area is about $51 \%$, it confirms a moderately strong degradation of the natural environment. Biogeographically, the vegetation of the study area is constituted by a heterogeneous set of elements of various origins dominated by the Mediterranean element. From the cartographic point of view, the study of satellite photos enabled us to confirm the degradation of the plant revetment by comparing the areas covered between 2003 and 2018. A notable diminution of this is reported, due to the man activity and his herds.
\end{abstract}

KEY WORDS Vegetation dune systems; flora; anthropogenic disturbance.

Received 22.12.2020; accepted 01.07.2021; published online 14.09.2021

\section{INTRODUCTION}

Assessing the State of Natural Environments is currently the main concern of Management, Conservation and Protection efforts. Biodiversity loss and ecological degradation is now widely recognized as the result of human action. Due to the growth in human population and excessive use of coastal resources, a significant deterioration in the quality of the coastal environments has emerged in the natural habitats (Clark, 1996; Kitsiou et al., 2002; Doygun et al., 2003). Coastal dune habitats are undeniably important ecosystems; they are characterized by a complex coast-to-inland environmental gradient which determines the habitat localization. Anthropogenic factors play a major current role in the organisation of vegetation struc- tures. An extremely rapid increase in population, determined a radical transformation of the environment caused by man, uncontrolled cultivation, widespread overgrazing, have severely disrupted the ecological balances that still existed years ago (Barbero et al., 1984).

Assessment of coastal dunes condition is therefore justified by taking into account the intrinsic fragility of this ecosystem on the one hand and strong pressures, both natural and anthropogenic, that threatens its integrity and functioning on the other hand. The dunes are therefore a potential reservoir of biodiversity but a threatened reservoir that the various regulations seek to preserve. Many studies have been focusing on the flora, basic vegetation, structure and dynamics of plant communities on the coastal habitats in the world (Carranza et 
al., 2008; Acosta et al., 2009; Carboni et al., 2009; Costa et al., 2011; Luca et al., 2011; Marcia et al., 2011; Tomaselli et al., 2011; Peinado et al., 2011; Monserrat et al., 2012; Qin et al., 2012; Rodnikova, 2012; Attorre et al., 2013; Ciccarelli, 2014).

In the Mediterranean context, many researches have pointed out that the composition of species and dominant life forms of coastal regions varies with different ecological factors, extreme conditions and time. For example, Luca et. al., (2011) showed a high correlation between degradation and habitat loss with coastal erosion, trampling and waste presence.

The problem of the coastal habitats alteration in Algeria is very widespread as a result of urbanization, industrialization, and tourism activities. In recent years various local studies conducted on various Algerian coastal sites have tried to draw up a precise ecological balance of these spaces, identify the nature of threats and failures in management (Ghodbani, 2001) on the marshes of Macta, (Larid, 2005) on the lakes of Réghaïa, (Toubal et al., 2014) on GuèrbesSenhaj, or (Dahou et al., 2011) on the El Kala lagoons and their maritime zone. Various coastal ecosystems assessments made by the Algerian Ministry of the Environment between 2000 and 2014 highlight the geomorphological, landscape and ecological specificities, but also their great fragility. However, despite this diagnosis, the elements of response on the real causes of environmental imbalances that affect a significant number of areas remain limited. That way, the protection measures adopted remain ineffective and out of step with local issues.

\section{MATERIAL AND METHODS}

\section{Study area}

The study area $\left(35^{\circ} 46^{\circ} 00.58^{\prime \prime} \mathrm{N} 0^{\circ} 49^{\prime} 33.00^{\prime \prime} \mathrm{W}\right.$ (Fig. 1) is located west of Cap Falcon, this rocky site forms a large bay open to the east. Upstream of this coastal site, it should be noted the expansion of agricultural holdings which risks damaging the coastal marine ecosystem through the use of fertilizers and phytosanitary products.

\section{Vegetation Survey}

Vegetation is in most cases the support of habitats; it is the most important indicator of environment conditions, particularly in environments with

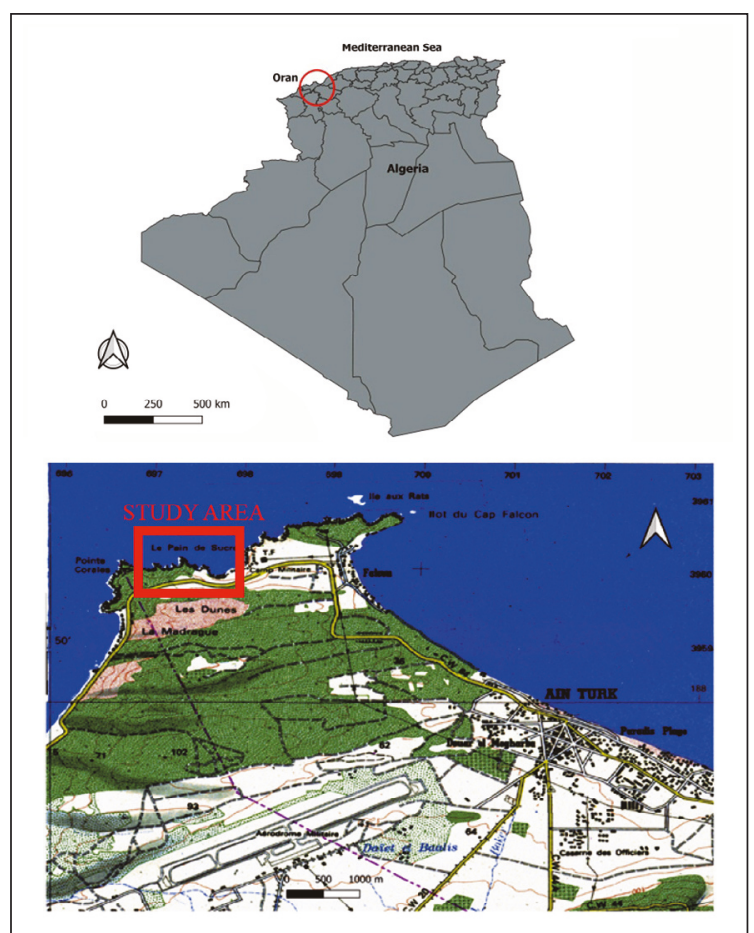

Figure 1. The study area and the location of sample plots.

very strong constraints such as coastal areas. Plants are arranged along an ecological gradient that develops from the coastline (Bertacchi \& Lombardi, 2013). A lot of studies have been done on flora, vegetation structure and dynamics of plant communities in the world (Carranza et al., 2008; Acosta $\&$ al., 2009; Carboni et al., 2009; Costa et al., 2011; Luca et al., 2011; Marcia et al., 2011; Tomaselli et al., 2011; Peinado et al., 2011; Monserrat et al., 2012; Qin et al., 2012; Rodnikova, 2012; Attorre et al., 2013). The coastal revetments, with the plant communities, constitutes the subject of our study. These plant communities range from the pioneer annual species on the shore to spontaneous, alien, woody and herbaceous vegetation in the back-coast area (Ciccarelli et al., 2012). In this investigation, we focused on the variations of the flora composition by assessing their frequency and diversity.

The floristic and habitat information are based on data collected during the spring and summer of 2018. Vegetation sampling was carried out along shore-perpendicular transects. The large number of plots studied allowed us to take into account almost all of the species present. We carried out 20 transects, perpendicular to the shoreline, 10 metres wide, deep as the foredune, at intervals of $100 \mathrm{~m}$ in the investigated coast. Along these lines, we 
recorded the presence/absence and width of the various plant communities according to Braun-Blaunquet's floristic analysis (1932). In addition, the life forms of these plant species, their families and their presence percentages within the habitats were also determined. Relative plant occurrences and coverages were estimated visually in each sample plots. The species frequency was calculated from the following formula:

$$
\mathrm{F} \%=(100 . \mathrm{n}) / \mathrm{N}
$$

Of which, n: it is the number of surveys or the species exists and $\mathrm{N}$ : it is the total number of surveys.

Durietz (1920) propose five classes depending on plant species frequency:

- Classe I: very rare species $0<\mathrm{F}<20 \%$

- Classe II: rare species $20<\mathrm{F}<40 \%$

- Classe III: frequent species $40<\mathrm{F}<60 \%$

- Classe IV: abundant species $60<\mathrm{F}<80 \%$

- Classe V: constant species $80<\mathrm{F}<100 \%$

The disturbance index which assesses the site degradation state by the invasion of annual species often sub-nitrophilic was calculated according to the formula adopted by Loisel et al. (1993).

$\mathrm{IP}=\frac{\text { Chamephyte numbers }+ \text { Theorophyte numbers }}{\text { total species numbers }}$

\section{Cartographic evaluation of La Madrague} dunes conservation state

In many coastal areas in the developing countries, dense population being placed next to the shoreline creates the more vulnerable areas. The study of plant cover evolution was performed by Visual interpretation on Landsat TM satellite images. The satellite image helps in detecting the changes in plant revetment. To obtain a better representation of the current situation, the comparison was made between two years 2003 and 2018 .

\section{RESULTS}

\section{Data analysis}

The study of plant formations on a natural site relies largely on their floristic composition. The floristic inventory constitutes a very important step to characterize a site from the point of view of its floristic diversity within plant groups. These are the first link in the trophic chain in the ecosystem and the support of all animal life; without plants, animals could not live since they are unable to manufacture all or part of their major constituents (Dupont \& Guignard, 2007).

\section{Distribution of plant species recorded}

Across the 67 designated readings of the coastal revetments that were studied in la Madrague, a total of 105 plant species were found belonging to 20 different families. The percentage distribution data of the plant species are given in Fig. 2. The study found that the identified plant species belong to different families. The family including the highest number of taxa was the Asteraceae $(24.32 \%)$, followed by Lamiaceae and Poaceae $(8.11 \%)$. Other families with the least number of species were Amaranthaceae, Boraginaceae, Brassicaceae, Fabaceae, Solanaceae including $5.41 \%$ of the species listed. The site is covered with characteristic plants that are easily distinguished, represented by halophytes and hydrophytes. We also note that the dominance of Asteraceae is probably due to species of this family which seem to be indifferent to the substrate, so tolerant to salt, which is confirmed by the results reported in the study carried out by Simonneau (1952) and Dubuis \& Simonneau (1960).

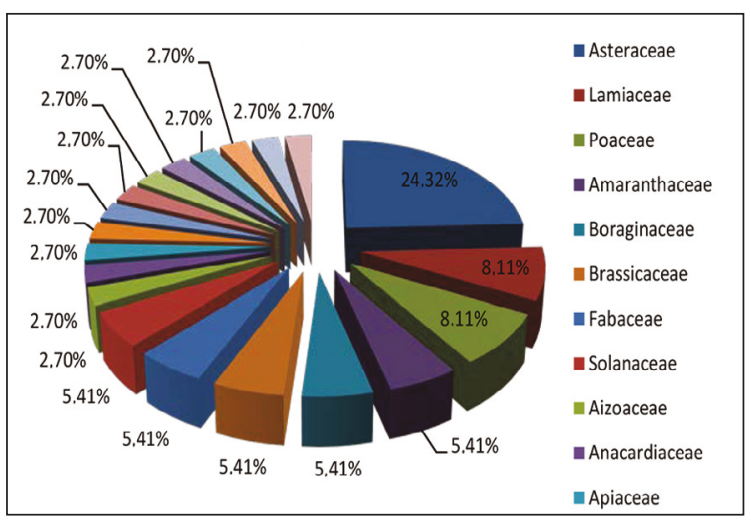

Figure 2. The distribution of plant species by families.

\section{The life-form spectra and origin of species}

Figure 3 shows the different life-form spectra 
of plant species in the revetment habitats of the studied area. Most of the biological spectra are present. Their analysis shows the larger frequency of therophytes with $32.43 \%$ represented by herbaceous species; these species are more adapted to drought than the Phanerophytes, which are more xerophilic.

According to Grime (1977), therophytes represent the expression of adaptation to disturbed habitats. This testifies to a degradation whose origin is anthropogenic action.

Several authors have focused their work on the therophytes extension origin:

- Either in adapting to the constraint of winter cold (Raunkiaer, 1934) or summer drought (Daget, 1980; Negre, 1966; Bouazza et al., 2004; Benabadji et al., 2004).

- Or to the disturbances of the environment by grazing, crops, etc. (Grime, 1977). According to Barbero et al. (2001), therophytization is considered to be the ultimate stage of ecosystems degradation with the dominance of subnitratophilic species linked to overgrazing.

- The presence of hemicryptophytes with 10 species can be explained by the presence of soils more or less rich in organic matter. This phenomenon was confirmed by Barbero et al. (1989) who reported that the richness of organic matter in a forest environment explains the abundance of hemicryptophytes.

The distribution of biological types at la Madrague is characterized as follows:

$$
\mathrm{TH}>\mathrm{HE}>\mathrm{CH}>\mathrm{NA}>\mathrm{GE}>\mathrm{PH}
$$

Figure 4 presents the spectrum of geographical origin of the species that occur in the revetments of

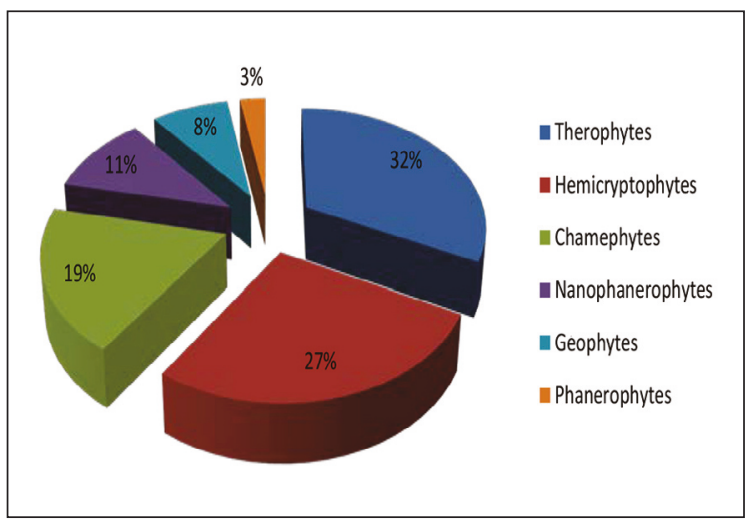

Figure 3. The distribution of plant species by Raunkier's life-forms. our study area. Biogeography is defined as the study and understanding of living organisms distribution in light of present and past factors and processes (Hengeveld, 1990). The biogeographic study also constitutes a real model for interpreting regression phenomena (Olivier et al., 1995). The biogeographical analysis of current flora can provide valuable information on the modalities of their establishment in the study region. On the biogeographic level, the vegetation of the study area is made up of set heterogeneous elements of various Mediterranean origins. The distribution of the inventoried taxa is determined from the flora of Algeria (Quezel \& Santa, 1962-1963).

The origin of the species in the study area is very diverse. The highest percentage (approximately $54.05 \%$ ) was recorded for species from Mediterranean region. The western Mediterranean elements follow with a percentage of $10.81 \%$. The other biogeographical elements are very poorly represented. Mediterranean elements are considered to be particularly suited to strong disturbance regimes under stressful conditions induced by unpredictable fluctuations in the Mediterranean climate.

\section{The disturbance index}

The IP disturbance index of the study area is around $51 \%$, showing a moderately strong degradation of the natural environment under the Influence of Natural and Anthropogenic Factors, and a disturbance and imbalance of plants, caused by the strong pastoral pressure, is noted in this site. Compared to other sites such as: Beni saf, Ghazaouet and Zenata Sidi Driss, Ouled Youcef and Ziatene of Honaine coast with indices that exceed $60 \%$ (Benmehdi,

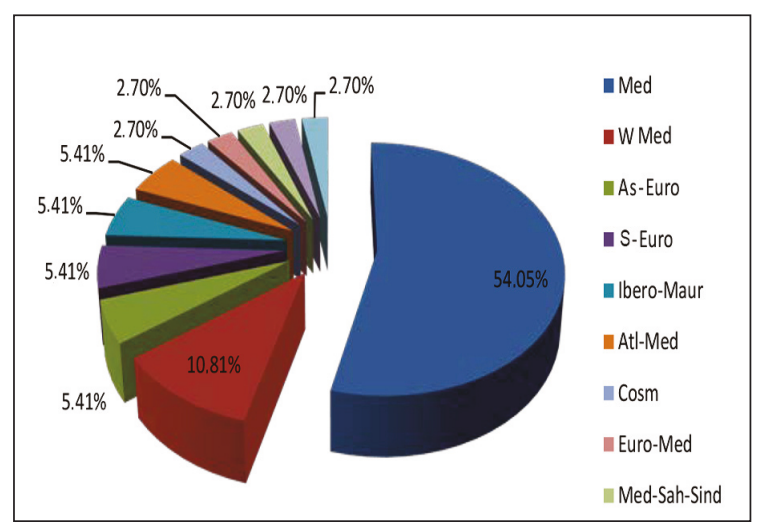

Figure 4. Distribution of species according to their biogeographic classification. 
2012; Cherif, 2012 in El Bouhissi et al., 2014), the Madrague site remains less disturbed but with regressive dynamic of its floral procession dominated by therophytes and hemicryptophytes.

\section{Frequency}

Statistical concept, used in vegetation analysis, it expresses the percentage (\%) of the number of surveys where the plant species is inventoried, compared to the total number.

The table below summarizes the distribution of species found in La Madrague area. After calculation, we distinguish three cases corresponding to three indices (Table 1).

Accidental species were present in $75.67 \%$ of surveys, while Accessory species in $13.51 \%$ of the surveys. Quite frequent species were found in $10.81 \%$ of surveys.

\begin{tabular}{|c|c|c|}
\hline Number of species & State & $\mathbf{\%}$ \\
\hline $\mathbf{8 0}$ & Accidental & 75.67 \\
\hline $\mathbf{1 4}$ & Accessory & 13.51 \\
\hline $\mathbf{1 1}$ & Quite frequent & 10.81 \\
\hline
\end{tabular}

Table 1. Characterization and frequency of vegetation indices.

\section{Vegetation dynamics}

In recent years (Fig. 5) major changes in occupation and land use have been noted. The studies reveal that the study area decreased from $2.332 \mathrm{~km}^{2}$ in 2003 to $0.832 \mathrm{~km}^{2}$ in 2018 .

\section{Pastoral activity}

Several studies have highlighted that environment degradation is due in large part to the human action (Fig. 5). Grazing in Algeria is old, in fact it eliminates the herbaceous layer and young regenerations by browsing, and reduces floristic diversity. Moderate to high human trampling intensity can decrease plant diversity, cover, and productivity, especially regarding rare and threatened coastal plants (Kerbiriou et al., 2008; Santoro et al., 2012; Farris et al., 2013; Fenu et al., 2013).

Bouazza et al. (1998) specify that the intense herd action modifies considerably the floristic composition. Sheep and goats participate with a higher degree in the vegetation degradation, than cattle. The animals choose the species and consequently impose an important selective action on the consumable biomass offered (Benabdelli, 1983). During the whole year, in the summer the herds occupy the agricultural land after harvesting agricultural products, and during the rest of the year, they graze in the coastal and forest environment. Faced with this situation, the scourge of overgrazing has become more dramatic, in parallel to the results which have been collected recently, in particular an imbalance in the floristic composition, a regression of the plant cover, a destruction of the superficial horizons and an erosion of the soil, an absence of the natural regeneration of the woody vegetation, occupation of the natural environments by the therophytes $(40 \%)$, etc.

\section{Dynamics of urban space}

Satellite images play an important role in urbanization. They help planners to have a global vision of the current situation and to consider future developments (Awad, 2003). An important evolution of land is recorded on the study area during carrying out our floristic surveys (Fig. 5) and by making a comparative study of the available satellite photos. Despite the clarity of the prohibitions, we notice in the Madrague area the arrival of new landowners. Anxious to make their investment profitable, they exploit the land without taking into account the norms of vegetation conservation. An anarchic housing construction is observed on site already inhabited by a family as well as a boat ga-

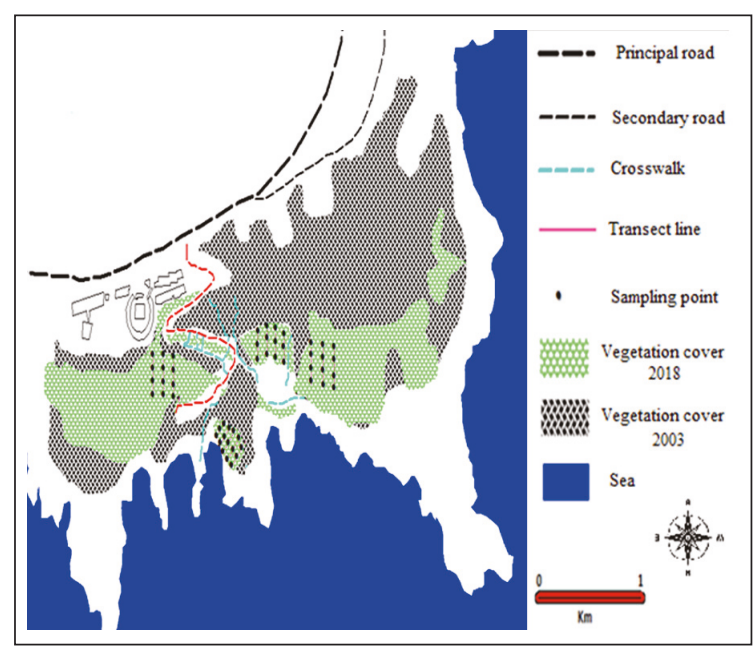

Figure 5. Vegetation cover in study area. 
rage project under construction. A significant decrease of the vegetation in the area is observed between 2003 and 2018. In the 2003 photo, we notice the absence of the factory. A widening of the road used to access trucks has considerably degraded the surrounding vegetation. Without protection from logging, grazing, poaching and other factors detrimental to maintaining the effective functioning of natural habitats, the extinction of a large number of species is inevitable.

\section{CONCLUSIONS}

The inventory carried out at our study station (La Madrague) allowed us to achieve the following characteristics: biological, phytogeographic followed by the distribution of families.

- The Asteraceae group undoubtedly dominates the field.

- The dominance of Mediterranean species.

- The biological type (Therophyte) widely dominates the station studied.

The Hemicryptophytes, Chamephytes, Nanophanerophytes, Geophytes and finally Phanerophytes come in second position. These last, according to (Barbero et al., 1989), require an environment rich in organic matter and a high altitude.

The IP disturbance index of the study area highlights a moderately strong degradation of the natural environment under the Influence of Natural and Anthropogenic Factors. An imbalance of plant populations, caused by the strong pastoral pressure, is noted in this study area.

The maps study reveals a degradation of the study area with a significant vegetation cover regression. The degradation of the study environment is due in large part to the action of man and his activities and lets a desolate spectacle. A significant evolution in land is also highlighted despite the clarity of the prohibitions.

It emerges from this study that it is extremely urgent to define a concentrated planning and protection policy for all the countries around the Mediterranean. If we want to save at least the remains still in place.

\section{REFERENCES}

Acosta A., Carranza M.L. \& Izzi C.F., 2009. Are there habitats that contribute best to plant species diversity in coastal dunes? Biodiversity and Conservation, 18: 1087-1098.

Attorre F., Maggini A., Traglia M.D., Sanctis M.D. \& Vitale M., 2013. A methodological approach for assessing the effects of disturbance factors on the conservation status of Mediterranean coastal dune systems. Applied Vegetation Science, 16: 333-342.

Awad Z., 2003. Exploitation combinée des images Spot multi temporelles et des photographies aériennes pour le suivi des évolutions en territoires occupés. Mémoire Ecole Supérieure spécialisé de télédétection, Université Toulouse, III.

Barbero M., Loisel R. \& Quezel P., 1984. Rôle des facteurs anthropiques dans le maintien des forêts et de leurs stades de dégradation en région méditerranéenne. Comptes rendus de la Société de biogéographie, 59: 475-488.

Barbero M., Loisel R. \& Quezel P., 1990. Les apports de la phytoécologie dans l'interprétation des changements et perturbation induite par l'homme sur les écosystèmes forestiers méditerranéens. Forêt méditerranéenne, 12: 194-215.

Barbero M., Loisel R., Medail F. \& Quezel P., 2001. Signification biogéographique et biodiversité des forêts du bassin méditerranéen. Bocconea, 13: 11-25.

Benabdelli K., 1983. Mise au point d'une méthodologie d'appréciation de la pression anthropozoogène sur la végétation de la région de Telagh (Algérie). Thèse de doctorat en Spécialisation Ecologie Faculté des sciences et techniques de Saint-Jérôme (Aix-Marseille), 185 pp.

Benabadji N., Bouazza M., Metge G. \& Loisel R., 2004 b. Les sols de la steppe à Artemisia herba-alba Asso. Au Sud de Sebdou (Oranie, Algérie). Synthèse n ${ }^{\circ} 13$.

Benmehdi I., 2012. Contribution à une étude phyto-écologique des groupements à Pistacia lentiscus du littoral de Honaine (Tlemcen, Algérie occidentale), Mémoire Magit., 159 pp.

Bertacchi A. \& Lombardi T., 2013. Diachronic analysis (1954-2010) of transformations of the dune habitat in a stretch of the Northern Tyrrhenian Coast (Italy). Plant Biosystems, 148: 227-236. https://doi.org/10.1080/11263504.2013.788572

Bouazza M. \& Benabadji N., 2000. Contribution à une étude bioclimatique de la steppe à Artemisia herbaalba Asso. dans l'Oranie (Algérie occidentale). Sécheresse, 11: 117-123.

Bouazza M., Mahboubi A., Loisel R. \& Benabadji N., 2001. Bilan de la flore de la region de Tlemcen (Oranie-Algerie). Forêt méditerranéenne, 12: 130-136.

Bouazza M., Benabaji N., Loisel R. \& Metge G., 2004. Caractérisation des groupements steppiques à Stipa tenacussima L. Synthése, 13: 52-60.

Carboni M., Carranza M.L. \& Acosta A., 2009. Assessing conservation status on coastal dune: a multiscale approach. Landscape and Urban Planning, 91: 17-25. 
Carranza M.L., Acosta A., Stanisci A., Pirone G. \& Ciaschetti G., 2008. Ecosystem classification for EU habitat distribution assessment in sandy coastal environments: an application in central Italy. Environmental Monitoring and Assessment, 140: 99-107.

Ciccarelli D., 2014. Mediterranean Coastal Sand Dune Vegetation: Influence of Natural and Anthropogenic Factor. Environmental management, 54: 194-204. https://doi.org/10.1007/s00267-014-0290-2

Ciccarelli D., Bacaro G. \& Chiarucci A., 2012. Coastline Dune vegetation dynamics: evidence of no stability. Folia Geobotanica, 47: 263-275.

Costa J.C., Neto C., Martins M. \& Lousa M., 2011. Annual dune plant communities in the Southwest coast of Europe. Plant Biosystems, 145(Supplement): 91-104.

Daget J. \& D. Depierre., 1980. Contribution a la faune de la République Unie du Cameroun. Poissoins du sanaga moyen et superieur. Cybium, 8: 53-65.

Dahou T., Elloumi M., Molle F., Gassab M. \& Romagny B., 2011. Pouvoirs, Sociétés et Nature au Sud de la Méditerranée, Paris/Tunis, INRAT/IRD/Karthala.

Doygun H., Berberoglu S., Alphan H., 2003. Hatay, Burnaz kıyı kumulları alan kullanım değişimlerinin uzaktan algılama yöntemi ile belirlenmesi. Ekoloji, 12: 4-8.

Dubuis A., Faurel L. \& Simonneau P., 1960. Note sur la flore et la végétation de la partie orientale de la Seguia et Hamra (Sahara espagnol).

Dupont F., Guignard J-L., \& Pelt J-M., 2007. Botanique: systématique moléculaire vol. 16, 285 pp.

El-Bouhissi M., Mehdadi Z. \& El Zerey W., 2014. Contribution à l'étude de la biodiversité floristique dans un écosystème montagneux Cas de versant sud de monts de Tessala (Algérie occidentale). Mediterranea Serie de Estudios Biológicos, 25: 53-89.

Farris E., Pisanu S., Ceccherelli G. \& Filigheddu R., 2013. Human trampling effects on Mediterranean coastal dune plants. Plant Biosystems, 147: 10431051.

Fenu G., Cogoni D., Ulian T.C. \& Bacchetta G., 2013. The impact of human trampling on a threatened coastal Mediterranean plant: the case of Anchusa littorea Moris (Boraginaceae). Flora, 208: 104-110.

Ghodbani T., 2001. Extension urbanistique dans le littoral d'Oran et ses effets sur l'environnement. Thèse de Magister. Université d'Oran. Département de géographie et de l'aménagement du territoire, $387 \mathrm{pp}$.

Grime J.P., 1977. Evidence for the existence of three primary strategies in plants and its relevance to ecological and evolutionary theory. American Naturalist, 111: 1169-1194.

Hengeveld R., 1990. Dynamic biogeography. Cambridge University Press.

Kerbiriou C., Leviol I., Jiguet F. \& Julliard R., 2008. The impact of human frequentation on coastal vege- tation in a biosphere reserve. Journal of Environmental Management, 88: 715-728.

Kitsiou D., Coccossis H. \& Karydis M., 2002. Multi-dimensional evaluation and ranking of coastal areas using GIS and multiple criteria choice methods. Science of the Total Environment, 284: 1-17.

Larid M., 2005. Analyse de durabilité dans le cadre du PAC "Zone côtière algéroise" (Algérie), Rapport final, Plan Bleu, Sophia-Antipolis, $71 \mathrm{pp}$.

Loisel P., Goffinet B., Monod H. \& Montes d'Occa G., 1993. Detecting major gene in an F2 population. Biometrics.

Luca E.D., Novelli C., Barbato F., Menegoni P., Iannetta M. \& Nascetti G., 2011. Coastal dune systems and disturbance factors: monitoring and analysis in central Italy. Environmental Monitoring and Assessment, 183: 437-450.

Marcia C., Marques M., Swaine MD. \& Liebsch D., 2011. Diversity distribution and floristic differentiation of the coastal lowland vegetation: implications for the conservation of the Brazilian Atlantic Forest. Biodiversity and Conservation, 20: 153-168.

Monserrat AL., Celsi CE. \& Fontana SL., 2012. Coastal Dune vegetation of the Southern Pampas (Buenos Aires, Argentina) and its value for conservation. Journal of Coastal Research, 28: 23-35.

Negre R., 1966. Les Thérophytes. Bulletin de la Société Botanique de France: Vol. 113, Mémoires: Colloque de morphologie (Les Types biologiques), pp. 92108.

Oliver L., Muracciole M. \& Reduron J-P., 1995. Premier bilan sur la flore des iles de la Méditerranée Etat des connaissances et observation Diagnostiques et proposition relatifs aux flores insulaires de Méditerranée par les participants au colloque d'Ajaccio. Corse. France (5-8 Octobre, 1993) à l'occasion des débats et conclusions, pp. 356-358.

Peinado M., Ocana-Peinado FM., Aguirre JL., Delgadillo J., Macias MA. \& Diaz-Santiago G., 2011. A phytosociological and phytogeographical survey of the coastal vegetation of western North America: beach and dune vegetation from Baja California to Alaska. Applied Vegetation Science, 14: 464-484.

Qin X.S., Zhang R.J. \& Xing F.W., 2012. A study on the flora and vegetation of Cat Dua Island, northeastern Vietnam. Pakistan Journal of Botany, 44: 1229-1232.

Quezel P. \& Santa S., 1963. Nouvelle flore de l'Algérie et des régions désertiques méridionales. C.N.R.S. Paris, 2 vol. 1170 pp.

Raunkiaer C., 1934. The life forms of plants and statistical plant geography. Oxford University Press, London.

Rodnikova I.M., 2012. Effect of environmental conditions on morphological, ecological and geographic characteristics of lichens in coastal habitats. Russian Journal of Ecology, 43: 97-100. 
Santoro R., Jucker T., Prisco I., Carboni M., Battisti C. \& Acosta A.T.R., 2012. Effects of trampling limitation on coastal dune plant communities. Environmental Management, 49: 534-542.

Simonneau P., 1952. La végétation halophile de la plaine de Perrégaux (Oran). Pubblication Université Algérie, $279 \mathrm{pp}$.

Tomaselli V., Pietro R.D. \& Sciandrello S., 2011. Plant communities structure and composition in three coas- tal wetlands in southern Apulia (Italy). Biologia, 66: 1027-1043. https://doi.org/10.2478/s11756-011-0113-3

Toubal O., Boussehaba A., Toubal A. \& Samraoui B., 2014. Biodiversité méditerranéenne et changements globaux: cas du complexe de zones humides de Guerbès-Senhadja (Algérie). Géographie Physique et Environnement, 8: 273-295.

https://doi.org/10.4000/physio-geo.4217 
